\title{
ノリ糸状体の黄斑病に関する吥究一III 発病に扣上ぼす水質の影響*1
}

\author{
谷口道子
}

(1977 年 8 月 12 日受理)

\begin{abstract}
Studies on the Yellow Spot Disease in conchocelis-III
Aquatic Factors Influencing the Development of the Yellow Spot Disease
\end{abstract}

\section{Michiko TANIGUCHI*2}

\begin{abstract}
Aquatic factors that influence the development of yellow spot disease in Porphyra conchocelis were examined.

1. When sterilized water drawn from a culture container in which the disease was very prevelent was used as the culture water in the experiment, almost all the conchocelis inoculated with the fractionated pathogen complex suffered from the disease. On the other hand, when the inoculated conchocelis were kept in fresh seawater, they did not suffer from the disease at all. There was remarkable difference between the sterilized culture water and the fresh seawater in their respective COD values and $\mathrm{NO}_{3}-\mathrm{N}$ concentrations; i.e., the $\mathrm{COD}$ value and $\mathrm{NO}_{3}-\mathrm{N}$ concentration was comparatively high in the sterilized culture water and low in the fresh seawater.

2. The appearance of the symptoms on inoculated conchocelis was affected by the $\mathrm{NO}_{3}-\mathrm{N}$ concentration and the amount of laver extract which were added to the culture water; i.e., the appearance of the symptom was restained at $\mathrm{NO}_{3}-\mathrm{N} 100 \mu \mathrm{g}$ at./liter or the laver extract $1.25 \mathrm{~g} /$ liter, was not always restained at $\mathrm{NO}_{3}-\mathrm{N}$ lower than $100 \mu \mathrm{g}$ at./liter or the laver extract lower than $1.25 \mathrm{~g} / \mathrm{liter}$, and was scarcely restained and spread quickly at $\mathrm{NO}_{3}-\mathrm{N}$ higher than $500 \mu \mathrm{g}$ at./liter or the laver extract $2.5 \mathrm{~g} /$ liter.

3. The appearance of the symptom on inoculated conchocelis was not restained at $\mathrm{pH} 5.0$ in culture water, and restained at the $\mathrm{pH}$ value higher than neutral.
\end{abstract}

ノリ系状体の黄班病に関する研究に批てて，病気の主因が加えられれば必ず発病する上らな宿主・環境条

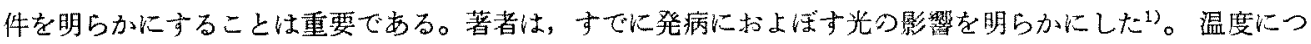

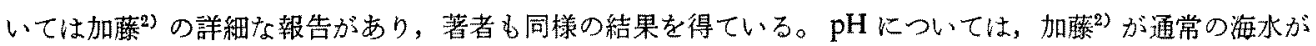
示す $\mathrm{pH}$ 洒の範团内では海水の $\mathrm{pH}$ 洒と発病との間にとくに密接な関俰はないと報告している。实際の培

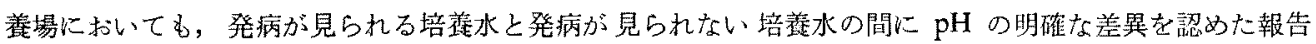
はない上らである。しかしながら，右田3 は中程度に繁茂した系状体は $2000 \mathrm{~lx}$ の照度で 5 日間培盖する 之培養水の $\mathrm{pH}$ が 9 以上に達すると報告している。実際の培養水に大きな $\mathrm{pH}$ の変動が認めら机ない場合

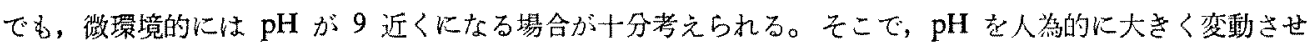

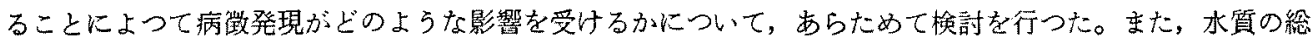
合的な発病条件については，全く明らか纪されていないので，むず，㧍う勢な発病の見られる培着水之新鮮 な海水について水質的発病条件の有無を比較し,つついて, 硝酸塩扣よび, リ抽出液の影響について試験を

*1 本研究の一部は文部省料学研究费によつた。

*2 高知罢水産武跲場 (Kochi Pref. Fish. Exp. Stat., Susaki, Kochi Pref, Japan). 
行つた。

\section{実 䮎 方 法}

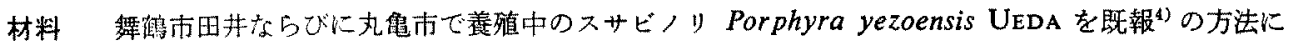

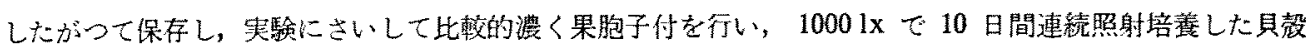
釆状体を用いた。

発病条件 試水を $200 \mathrm{ml}$ 容減苜ガラスビーカーに入れ, 上述の貝殼采状体を $1 \sim 1 / 2$ 枚浸漬し， $25^{\circ} \mathrm{C}$ の邲耶器内に壏いた。

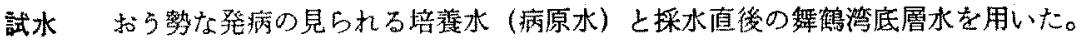

発病におよほす水質の影響に関する実験上述の試本を用いザイッろ過器によるる過隇菌区と嶚沸隇菌 区を設けた。をれぞれに上述の貝殻釆状体を浸潰し，これに前報で述べた病原体を接種し上述の発病条件下 に置いた。たたし，病原体の接種によつて試水の化学的成分が変化するのを防ぐため, $6500 \mathrm{G}$ 上澄, $12000 \mathrm{G}$ 沈激で得られた区分をさらに二回人工海水で洗浄し，これの $12000 \mathrm{G}$ 沈汯区分を病原体とした。この他に， 硝酸塩と八リ抽出液を人工海水に種々の濃度に添加し，これらについても同様な方法で発病に扰上ぼす影響 を見大。人工海水の組成俚蒸留水 $1 l$ 中下 $\mathrm{NaCl} 23.5 \mathrm{~g}, \mathrm{MgCl}_{2} 5.0 \mathrm{~g}, \mathrm{Na}_{2} \mathrm{SO}_{4} 3.9 \mathrm{~g}, \mathrm{CaCl}_{2} 1.1 \mathrm{~g}$, $\mathrm{KCl} 0.7 \mathrm{~g}, \mathrm{NaHCO}_{3} 0.2 \mathrm{~g}, \mathrm{KBr} 0.1 \mathrm{~g}$ を溶解したるのである。

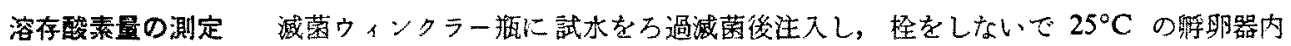
で一昼夜放置した後, 常法に従つて測定した。

CODの測定 万過隇菌後の試水につて常法に上り测定した。

アンモニア態空素，覀硝酸態窒素，硝酸態窒素の定量 それぞれ，ネスラー試薬，GR 試薬，カドミウ ムアマルガムを用いて常法により測定した。

発病におよはす $\mathrm{pH}$ の影響に関する実験＼cjkstart病原水の $\mathrm{pH} 5,6,7,8$ の 段階に調整し, 每日一回 の $\mathrm{pH}$ 修正を行いながら，上述の発病条件下に罳いた。酸端な $\mathrm{pH}$ 值に上る生理障害をチェックするため に，新鮮な海氷を用いて病原体非接種区を設け，同様の操作を行い、対照区とした。

\section{結果ならびに考察}

発病におよほす水質の影響 Table 1 に示されるように, 新鮮な海水は病原体が接種されているにもか か和らず一例の発病も認められなかつた。一方, 预ら勢な発病の見られる培盖本を隇菌した後環境水として 用いた場合には隇菌方法のいかんにかかからずすべて発病が見られた。このことは黄斑病が宿主の状態や光 条件のみならず，水質に上っても発病が㧍おいに左右されることを意味している。たとえ強力な病原体が存

Table 1. Effect of the quality of water on the appearance of yellow spot disease of Porphyra conchocelis when the conchocelis was infected with the pathogen complex

\begin{tabular}{lccc}
\hline \multirow{2}{*}{ Water } & \multicolumn{3}{c}{ Appearance of the disease** } \\
\cline { 2 - 4 } & Experiment 1 & Experiment 2 & Experiment 3 \\
\hline Culture fluid* sterilized by filtering & +++++ & +++++ & +++++ \\
Culture fluid* sterilized by boiling & +++++ & +++++ & +++++ \\
Fresh seawater sterilized by filtering & - & - & - \\
Fresh seawater sterilized by boiling & - & - & - \\
\hline
\end{tabular}

* Culture fluid in which the yellow spot disease was strongly spreading.

** The degree of the symptom was shown as the area of the yellow spot in individual shell. $-:$ no yellow spot, $+: 1 / 20,++: 1 / 4,+++: 1 / 2,++++: 3 / 4,+++++:$ the whole area. 
Table 2. Analysis of the culture fluid and the fresh sea water

\begin{tabular}{lccccc}
\hline \hline Water & $\begin{array}{c}\mathrm{O}_{2} \\
(\mathrm{~m} / \mathrm{liter})\end{array}$ & $\begin{array}{c}\mathrm{COD} \\
\left(\mathrm{O}_{2} \mathrm{mg} / \mathrm{liter}\right)\end{array}$ & $\begin{array}{c}\mathrm{NH}_{3}-\mathrm{N} \\
(\mu \mathrm{g} \text { at./liter })\end{array}$ & $\begin{array}{c}\mathrm{NO}_{2}-\mathrm{N} \\
(\mu \mathrm{g} \text { at./liter })\end{array}$ & $\begin{array}{c}\mathrm{NO}_{8}-\mathrm{N} \\
(\mu \mathrm{g} \text { at./liter })\end{array}$ \\
\hline Culture fluid* & 3.0 & 4.24 & undetectable & 1.4 & 335.5 \\
Fresh seawater & 3.9 & 0.53 & undetectable & 1.5 & 1.5 \\
\hline
\end{tabular}

* Culture fluid in which the yellow spot disease was strongly spreading.

Table 3. Effect of nitrate on the appearance of yellow spot disease for infected Porphyra conchocelis

\begin{tabular}{ccc}
\hline \multirow{2}{*}{$\begin{array}{c}\text { Concentration } \\
\text { of nitrate } \\
\text { ( } \mu \text { g at./liter) }\end{array}$} & \multicolumn{2}{c}{ Area of yellow spot* } \\
\cline { 2 - 3 } & Experiment 1 & Experiment 2 \\
\hline 10 & ++ & + \\
20 & - & - \\
100 & - & ++ \\
500 & +++ & ++ \\
1000 & +++ & ++ \\
5000 & ++ & ++++ \\
10000 & +++ & ++++ \\
\hline
\end{tabular}

* The degree of the symptom was shown as the area of the yellow spot in individual shell. - : noyellow spot, + : 1/20, $++: 1 / 4,+++: 1 / 2,++++$ : $3 / 4,++++$ : the whole area.
Table 4. Effect of the extract of the blades of Porphyra on the appearance of the yellow spot disease

\begin{tabular}{ccc}
\hline \hline $\begin{array}{c}\text { Amount of } \\
\text { extract } \\
(\mathrm{g} / \text { liter })^{* *}\end{array}$ & \multicolumn{2}{c}{ Area of yellow spot* } \\
\cline { 2 - 3 } & Experiment 1 & Experiment 2 \\
\hline 0 & + & +++ \\
1.25 & + & - \\
2.5 & ++ & ++ \\
5 & ++++ & ++++ \\
\hline
\end{tabular}

* The degree of the symptom was as the area of the yellow spot in individual shell. - : no yellow spot, $+: 1 / 20,++$ : $1 / 4,+++: 1 / 2,++++: 3 / 4,+++++$ : the whole area.

** The wet weight of the blades of Porphyra.

在し，前報〉で明らかにされた知りらるかぎりの発病条件を以てしても，なお水筫いかんによつては病徽が 全く出現しないといらことは，黄斑病の特徽として重要視しなりればならない上らに思われる。また，前報 の発病実験におい、て病原体浮遊液としてろ過隇菌を施した病原水を用いたことは，今回の実験結果から考え て適切な措置であつたことが確諗できる。この実験からはいかなる物筫が発病を保証しているのか明らかて はないが，熱㚭理に対してる安定な物質であることが推察される。そこで,これら二つの試水の化学分析を

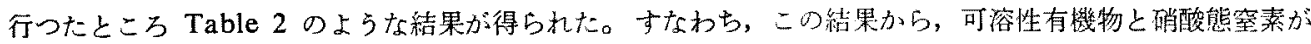
発病を促進している可能性がらかがかれる。

硝酸塩とノリ抽出液が発病におよほす影響 Table 3, Table 4 に示される実騟結果が得られた。これ によると，実験ごとに多少の变動はあるるのの，いずれの場合もある濃度域に拈いて病徵の発現が抑制され

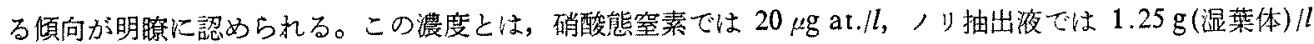

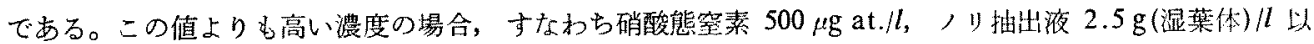
上て病徽発現は安定し, しか子, その病徽の進行む助長されている。

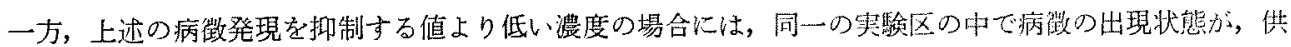

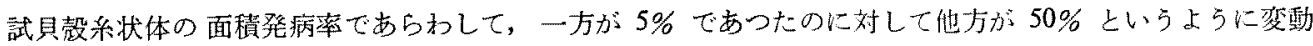
の著しい結果が得られた。これは水質的に緩衝能力が小さいために不安定な状態に置かれているものと考支 られる。

以上のことから，硝酸塩やノリ抽出夜は発病条件として重要な要素であり，笑際に病気を防除する5点て む，また実験的研究を進めるらえからも十分注意を払ら必要のあることが明らかになつた。今回用いたノり 葉体の品質は普通程度のものであつた。，莱体の成分含有量は采焦状態でかなり変動するので, 今回病徽 
Table 5. Effect of the $\mathrm{pH}$ on the yellow spot disease of Porphyra conchocelis. Five pieces of shell was used in each experiment.

\begin{tabular}{ccccc}
\hline \hline \multirow{2}{*}{ Water } & $\mathrm{pH}$ & \multicolumn{3}{c}{ Number of shells } \\
\cline { 3 - 5 } & & $\begin{array}{c}\text { Many small } \\
\text { yellow spot* }\end{array}$ & $\begin{array}{c}\text { A few small } \\
\text { yellow spot }\end{array}$ & No symptom \\
\hline \multirow{2}{*}{ Culture fluid infected with } & 5.0 & 5 & 0 & 0 \\
pathogen complex & 7.0 & 3 & 2 & 0 \\
& 8.0 & 1 & 4 & 0 \\
\hline Fresh seawater uninfected & 5.0 & 0 & 5 & 5 \\
& 8.0 & 0 & 0 & 5 \\
\hline
\end{tabular}

* The area where the symptom appeared is wider than $80 \%$ of an shell surface.

発現との関連で得られた数値は絶対普㴜的なものとはいえない。しかしながら，抽出夜が傾向として硝 酸態窒素之同様の効果をしめしたことは，ビタミンやフミ/酸等の有機成分が病徽発現にあまり大きな役割 を持つていないことを示すものと思われる。また，当初の目的である「病気の主因が加えられれば必らず発 病する環境条件」として，高濃度の硝酸塩添加が挙げられることも明らかになつた。

発病におよはす pH の影響 これについて Table 5 に示すような結果が得られた。これによると, 供 試された貝殻系状体 5 枚のらち面皘発病率が 80\% を示した手状体の枚数は pH 5 において 5 枚であり， $\mathrm{pH}$ が高くなるに徒つて減少し， $\mathrm{pH} 8$ においては 1 枚も出現しなかつた。一方，わずかに微粒斑を形成

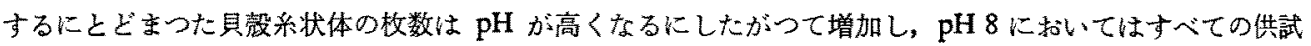
貝殸系状体がこの状態のますで病状が進行しなかつた。これらのことから, 強制的に $\mathrm{pH}$ を調整した場合 には，中性ないしアルカリ性は発病を抑制する作用をおよ注していると考えられる。同時に行つた対照区の 病原体非接種区はいずれの $\mathrm{pH}$ 区に扎いても全く発病が認められなかつた。このことは上述の酸性側で生 じた病改が $\mathrm{pH}$ の低下による生理障害ではなく, 黄斑病の病原体によつてひき抏こされた病徽そのいのであ ることを示すものである。

以上の結果から $\mathrm{pH}$ むたノり系状体の黄斑病の発病条件として重姴であることが明らかである。すな わち, 当初の目的である「病気の主因が加えられれば必ず発病する条件」を满すためには水質が $\mathrm{pH} 5$ 近く の酸性であることが望ましい。中性またはフルカリ性においても病徵の発現は認められるものの, 典型的症 状とはかなりのへだたりがあり，条件としては不適当である。従来行われた発病実験はすすべて $\mathrm{pH}$ を調整 することなく実施され良好な結果を得ている。これらの事実と今回の実験結果は一見矛盾するよらに思われ る。しかしながら，尾形听は糸状体の $\mathrm{pH}$ は 4 5 であり常に酸を放出して貝殻采状体を溶解していると

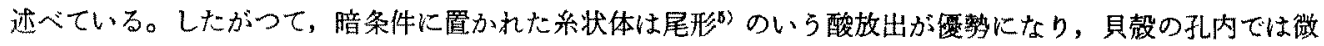

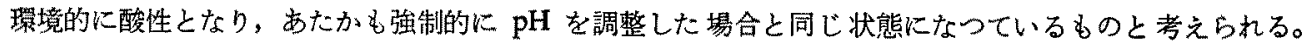
前報1) 病徽発現は暗条件下に置かれた場合にのみ見られることを明らかにしたが，pH の条件がこのこと によつて同時に充足されていたものと考えられる。

要約

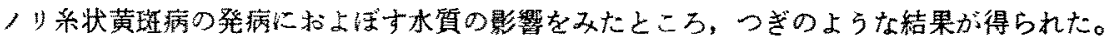

1. 水質は黄斑病の病微発現に重要な影響をおよぼした。すなわち，発病実験に执いて，病原体を接種し

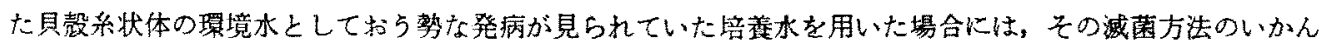
にかかからずよく発病したのに対して、新鮮な海水を用いた場合には，系状体や病原接種方法が同一である にもかかわらず全く発病しなかつだ。これら両者の水筫分析を行つたところ，硝酸態窒素と COD に顕著 


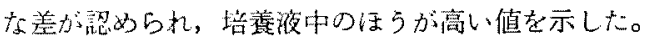

2. 黄斑病の病徽は，㻴境水中の硝酸態窒素ならびにノリ抽出液の濃度に上つてその出現を左右された。

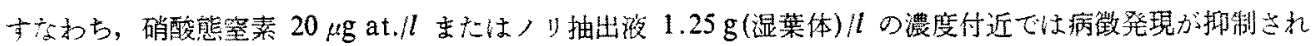
た。しかし，これ以下の濃度，上くに栄荃塩無添加区では病政発現が不安定であつた。一方, 硝酸態案素

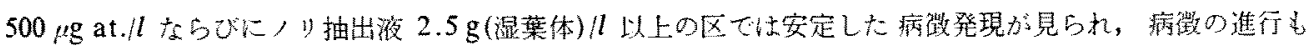
促進已机た。

3. 強制的に $\mathrm{pH}$ を調整した場合， pH 5 において最も発病率が高く，中性からアルカリ性になるにし たがつて発病率が低下した。

おわりにこの研究を続计るにあたり，数々のご援助をいただき，校閱の労をとつていたたいた高知大学 丧学部烟幸彦教授に深謝の意を表します。

$$
\text { 文献 }
$$

1) 谷口道子：本誌，36，686-691 (1970)。

2) 加藤 孝: 德島祘水産試駼場調查研究業績, 10, 1-66, pls. 1-10 (1967).

3) 右田清治：長崎大学水産学部研究報告, 8, 207-215 (1969).

4) 谷口道子：本誌, 35, 333-335 (1969).

5) 尾形英二: 水産請習所研究報告, 10, 69-500, pls. 1-12 (1961). 